\title{
障害の原因觉明から親・子どもの 日常生活に立朋した運動へ
}

\section{——先天性四肢障害児父母の会の 1970/80 年代——}

\section{堀智久*}

本稿の目的は, 先天性四肢障害児父母の会の運動の展開を追い, そのなかで 親たちが，いかにしてその主張の有り様を転換させてきたのかを明らかにする ことである。

先天性四肢障害児父母の会は，1975 年に設立され，環境污染がさまざまに 問題にされた時代にあって，子どもの障害の原因究明を訴える運動として始め られた．親たちは自らを被害者家族として位置づけ，一方では国・厚生省に催 奇形性物質の特定・除去を求め, 他方ではシンポジウムや写真展の活動を通じ て, 障害をもった子どもが二度と生まれないように社会啓発を展開していく. こうした訴えはそれ自体，親たちにとつて，解放の効果をもつものであった。 だが，1980 年代に入ると，この原因究明の訴えは次第に行き詰まりを見せ るようになる。とりわけ，障害者本人による原因究明活動への違和感の表明や 「障害をもっていても不自由ではない」という主張は，この運動の質の転換を 決定的なものにした。親たちはその後, 親と子どもの当事者性の相違を認識し, 親子の日常生活に立脚した活動を展開していく．子どもが主役のシンポジウム や子どもの生き生きとした姿の写真が並べられた写真展の活動を通じて，「障 害をもった子どものいる暮らしはけっして不幸ではない」ということを示して いく.

本稿では，こうした先天性四肢障害児父母の会の運動の展開から，1970 年 代および 80 年代における運動の質の相違を明らかにしていく.

キーワード：障害, 家族, 社会運動

\section{1 問題 関心}

\section{1 研究目的}

1970 年代以降，多くの先進資本主義諸国で障害者解放運動が台頭する．米国の 自立生活運動, 英国の「隔離に反対する身体障害者連盟」(UPIAS) 等がそれであ り, 日本では，70 年代以降の「青い芝の会」の運動が，障害者解放運動の先駆的 
存在である。

一方で, 欧米に比して, 日本の障害者解放運動が特殊であるといわれるのが, 日 本の障害者解放運動では，「脱施設」の主張のみならず，「脱家族」の主張がなされ てきた点である（要田 $1994 ： 66$ ). たとえば，日本の「青い芝の会」の横塚晃一は， 障害者解放運動のなかで,「泣きながらでも親不孝を詫びながらでも, 親の偏愛を けっ飛ばさねばならないのが，我々の宿命である」（横塚［1975］1981：17）と述 べて, 親のもつ愛情ゆえの抑圧性を批判した。また，「親はこの子のためにとやっ ていることが結局は私達にとっては非常に抑圧になる」(横塚［1975］1981：143） といったように, 親による子どもを慮っての善意の営みは, 必ずしも障害者にとつ ては首肯されるべきものではないこと，むしろ親と子どものあいだには明瞭な視点 の分断があることが示されてきた.

一方で，日本の障害者家族を扱う社会学的研究に扔いても，これらの提起を踏ま えたうえで検討が進められてきた。まず挙げられるのが，障害者が「脱家族」を主 張するその契機ともなった，家族内部の抑圧的な様相を明らかにしょうとする研究 である（岡原 1990 ；土屋 2002 ；春日 2001）。たとえば，岡原正幸は，「脱家族」 の意義を読み取る試みのなかで，障害者にとって問題なのは，「家族内部の感情的 な巻き込まれが強く, 閉鎖的な空間が作られてしまい, 社会に開かれる契機を失っ てしまうこと」(岡原 1990 ：78）であると指摘している.

次に挙げられるのが，たとえば，「青い芝の会」によって「親は敵だ」という主 張がなされてきたことから, 親の自己変容の可能性に注目する研究である（要田 1986 ; 石川 1995).たとえば，要田洋江は，「親たちは差別される対象であると同 時に差別する主体でもあるという両義的な存在である」が，「親たちは，いつまで も“とまどい”の状態にとどまっているわけではな」く，「障害者差別を表わす言 説に対して，その不当性を“抗議”しはじめる」（要田 $1986 ： 16 ）$ と指摘している. こうした要田に代表される研究は, 必ずしも親が障害者を排除する存在とはならな いことを指摘する点で評価できるものの，実際に親たちがいかにして「子供の側に

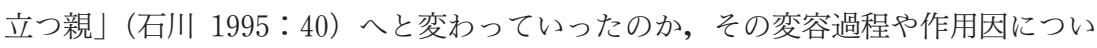
てはほとんど明らかにしていない。

本稿は, むしろ親の運動の具体的な展開過程に焦点を当てることによって, 親た ちはいかなる活動の実践によって, 子どもの視点に気づいていくのかを検討しょう とするものである. 具体的には，1970 年代および 80 年代を中心に，先天性四肢障 害児父母の会（以下，「父母の会」） ${ }^{1)}$ の運動の展開を追う. 本稿では, 現在積極的 に「子どもの障害はあってもよい」という主張を行う「父母の会」の運動を事例と して，そのなかで親たちが，いかにしてその主張の有り様を転換させてきたのかを 明らかにしていく。

\section{2 高度経済成長期における親の運動の主流と批判の動き}

ここではまず，それまであった親の運動の主流とこれへの批判の動きから，本稿 
で「父母の会」の運動を取り上げる意義を明らかにしておきたい.

「父母の会」は 1975 年に設立されるが，高度経済成長期における「障害児の親」 の運動の主流は, 重度障害児者を収容するための施設の拡充を求める運動である. この時期, 日本の障害者福祉は, それまで中心であった更生可能な軽度障害児者を 対象とする施策から, 常時介護を必要とする, 重度障害児者を対象とする施策へと 施策の重点を移していく，とりわけ，重度障害児者を収容するための施設の拡充は， この時期の施策の中心であり，なかでも「全国重症心身障害児(者)を守る会」を噮 矢とする親の陳情運動は，この施策の内実に直接的な影響を及ぼしてきた．重度障 害児者をもつ親たちは，「施設にあずけて親の責任をのがれようとしているのでは ない」「家庭が崩壊されてしまうから」(全国重症心身障害児(者)を守る会 1965 ： 29）といったように, 親としての責務を強調しながら，自らの抱えている過重な介 護負担や親亡き後の不安を社会に訴えていく ${ }^{2)}$.

だが，こうした大きな流れともなっていた施設拡充の動きは, 必ずしも障害者に よって受け入れられ求められてきたわけではない.とりわけ, この時期, 親と子ど もの視点の相違を鮮明にした出来事として，1970 年 5 月に横浜で起きた母親の重 度障害児殺害事件に対する減刑嘆願運動とそれへの批判の動きがある。

あらかじめ付言するならば，これまでにも近親者による障害児殺しや無理心中は 珍しくなかった。また，親の側による減刑嘆願運動もこのときがはじめてではな (3).さらにいえば，世間の反応は，多くの場合に殺した側に同情的であり，障害 児が殺人の被害者であるという認識はなかった。そして，このときもまた，上の 「重症心身障害児(者)を守る会」を含む「神奈川県心身障害者父母の会連盟」は， 「施設や家庭に対する療育指導もなく, 生存権を社会から否定されている障害児を 殺すのは，やむをえざる成り行きであり，福祉行政の貧困に抗議する」とする抗議 文を市長に提出した。これに対して，「青い芝の会神奈川県連合会」によって，は じめて障害者の側による減刑嘆願運動への批判が展開されたのである。たとえば, 「青い芝の会」側の小山正義は，1970 年 9 月 6 日，横浜市内小児療育センターで開 かれた「神奈川県心身障害者父母の会連盟」との話し合いの席4)で，「あななた方は このような事件が起きると，すぐ福祉行政の貧困をその原因にあげ，施設があれば こんなことにはならなかった』と言うが，『施設は親の要求でつくられたものであ つて, 決して障害者の立場からつくられたものではない』（青い芝の会神奈川県連 合会 $1970 ： 5$ ）と述べて, 親の側を批判した。この減刑嘆願運動への批判の動き によって，はじめて障害者の側から「この［障害児殺しの］場合一番大切なはずの 本人 (障害者) の存在はすっぽり抜け落ちている」（横塚［1975］1981：80）こと, 施設拡充の動きもまた「親すなわち健全者」の意向のみによって推し進められたこ とが批判されたのである.

これに対して，本稿で取り上げる「父母の会」の運動は，必ずしも親の視点のみ から展開されてきたわけではない. 後述するように「父母の会」の運動は, 1980 年代以降, 子どもの視点に立った運動へと, その主張の有り様を転換していく. 高 
度経済成長期における親の運動の主流がもつぱら親の視点のみから展開され，その 後，必然的に親と子どもの視点の対立をもたらすものであったとすれば，「父母の 会」の運動は，親の側から親と子どもの視点の相違を認識していくものとして検討 に值する。

\section{$2\lceil$ 父母の会」の結成}

1975 年 8 月,「父母の会」は，ひとりの専業主婦の呼びかけによって結成された。 野辺明子氏が，毎日新聞（1975 年 2 月 6 日）の「女の気持ち」欄に「先天異常の 子をもって」という文章を投書したことが，そのきっかけである．その後も野辺氏 が，先天性四肢障害児をもつ親の立場として，雑誌やテレビなどのメディアに投 稿・出演したことから，同年 8 月 31 日，東京都立熟宮高校の一室を借りて，先天 性四肢障害児をもつ 54 家族が集まり設立総会が開かれた。

だが，この設立総会は，「[総会前に全国に散在する親の］仲間同士で十分な討議 を重ねて準備する，という事は事実として無理」であり，「とりあえず，皆が一堂 に会し，今後の事について考えていく共通の場」(先天性四肢障害児父母の会 1975：2）として開かれたものであった。専門家ではない親たちのみによって結成 されたために，「[『父母の会』が $]$ 今後どのように活動を続けていくのか，といっ た基本的かつ重要な問題についてはすべて発足後に検討する」「とにかく，常任委 員会で話し合って決めていこう」（先天性四肢障害児父母の会 1995：3 ）というこ とになる．発足後，はじめて開かれた常任委員会では，今後の具体的な活動方針と して，「1. 先天性四肢障害の原因究明に関すること，2．先天性四肢障害の実態究 明に関すること，3．先天性四肢障害児の医療対策に関すること，4．先天性四肢障 害児の教育問題に関すること，5．先天性四肢障害児の救済補償に関すること，6. 先天異常 (児) 問題, 児童福祉などに関し, 他の親睦団体・運動団体・研究グループ との交流をはかること，7．会員相互の交流・親睦のための催しを計画すること」 （先天性四肢障害児父母の会 $1995 ： 292-3 ）$ が決議された。すなわち，「父母の会」 の運動は，療育問題などへの取り組みのみではなく，むしろ原因究明の訴えを柱に 据えて展開していくことが決められたのである.

そしてまた，「父母の会」の運動において特徵的であるのが，具体的な療育問題 などに関する制度的要求を行うというよりは，原因究明の訴えを通じて，「子ども の障害が誰にでも起り得ること」「子の障害について，個の問題であると同時に社 会的な問題である」（先天性四肢障害児父母の会 1995: v）ことを訴える運動とし て始められた点である，たとえば，「父母の会」と同じく先天性四肢障害児をもつ 親の会であり，また設立前にはこの会の幼児部として始めることも検討されていた 「子どもたちの未来をひらく父母の会（サリドマイド児をもつ親を中心とした会）」 を例にとれば，野辺氏が「[会長の飯田進氏が］厚生省児童家庭局とツーカーな関 係であった」「[この会は］随分打金をもらっていた」5)と語るように，この会は多 
くの寄付金や助成金を得て，小児療育センターや医療センターなどの福祉事業を興 していく，これに対して，「父母の会」の場合には，「施設をつくって欲しい」「医

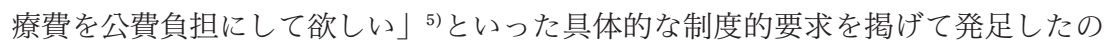
ではない，そうではなく，「障害児を生んだ親への偏見や差別」に対抗する運動と して，「指のない子供，あるいは他とどこか違った形の者への世間や身内の理解」 （先天性四肢障害児父母の会 1975：1）を求める運動として始められたのである. 実際に「父母の会」の原因究明の訴えが, 親に対してどのような効果をもったのか については, 3.3であらためて論じる。

\section{0 年代一一家族/科学（原因究明）への期待}

\section{1 被害者家族としての位置づけ}

周知のとおり，1960 年代後半以降，全国各地で環境問題を提起する住民運動が 沸き起こる. 住民運動とは, 生活する地域住民によって担われた運動であり, 生活 環境の保護・改善要求を揭げて取り組まれた運動である（似田貝 1976：203-7). 地域住民による生活者の視点から, 高度経済成長のもたらした急速な工業化・地域 開発による産業構造の歪みに対抗する運動として展開された。

これに続いて，1970 年代以降には，障害者解放運動，女性解放運動といった各 種マイノリティ運動が多発する（梶田 $1991 ： 189)$. 本稿で取り上げる「父母の会」 の運動もまた，この各種マイノリティ運動のひとつとして捉えられるが，だが設立 当初の「父母の会」の運動についていえば，むしろ環境問題を提起する住民運動の 特色こそを色濃くもつものである.たとえば，「父母の会」の設立前年，1974 年に はサリドマイド裁判が和解決着し, またこの時期には, さまざまな環境污染物質 (スモン, PCB, DDT 等) が問題にされた。 そして,「父母の会」の子どもについ てもまた，こうした一連の環境污染によって障害が発生したのではないかと疑われ たのである.

たとえば, 当時,「父母の会」のなかで, 子どもの障害は環境污染によるもので はないかと疑われた点については，西村圭也氏が次のように語っている.

そのなんでこういう子が生まれるんであろうかっていう，それは避け難い現 象であるとは思わなかったわけですよ，誰かが悪さをしていると, 誰かが環境 を破壊していると, 薬が間違って使われていると. 農薬が, 洗剤がっていう, 誰かがこういう子どもたちをつくっているに違いないという思いがあって, 腹 が立っていたわけですよね.だから原因究明っていう言い方の裏には, 子ども たちの指を奪ったのは誰だっていう憤りがありますよ6).

西村氏の語る，「父母の会」で当時，「子どもの障害は人為的につくられたもの」 「われわれは被害者家族である」といった捉え方がなされていたという点は，けっ 
して氏の思い込みではない.たとえば，「父母の会」の当時の資料を見るならば， 「[子どもの先天異常は］現代社会に内在する恐怖」であり，「人間生活よりも産業 の発展を優先させようとしてきた社会のあり方，その中に子どもの異常の原因が潜 んでいる」. そして「次に起きる不幸を食い止めるためにはその恐怖の実態を訴え， 叫び，世に知らしめ，ではどうすればいいのか，市民を取り込みながら考光続けて いかなければならない」（先天性四肢障害児父母の会 1978：1）といったように， 容易にこの捉え方が会全体に共有されていたことが理解できる。また同様に，奇形 ザル問題研究会らとともに,「父母の会」主催のシンポジウムや写真展の活動など で多用されていた「人類への警告」というテーマからは，「私どもの子供の障害の ほとんど全部が，なんらかの外因によるものである」，それゆえに「私どもの抱え ている障害児問題は，私どもの一人一人の問題ではなく」「人類の生存そのものの

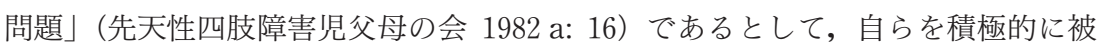
害者家族として位置づけることで，子どもの障害を社会全体の問題として理解させ ようとしていたことが確認できる。

\section{2 原因究明活動の展開}

こうして「父母の会」の運動は, 環境破壊がさまざまに問題にされた時代にあっ て, 子どもの障害の原因究明を訴える運動として始められる，たとえば，「父母の 会」の設立趣意書には，国・厚生省に「疫学調査の充実，先天性四肢障害児の原因 究明・実態究明」を要求し, 環境要因である催奇形性物質の特定・除去を目指す。 これによって，「家族や子ども自身が受けた苦しみや悲しみを二度と繰り返」さな いように，「こうした子どもが二度と生まれないように求めていく」(先天性四肢障 害児父母の会 1995：341）と明記されている．具体的には，「父母の会」の原因究 明の訴えは，次のような活動によって展開されていく.

まず，親たちがはじめに取り組んだのは，会員のカルテ収集である.カルテ収集 の目的は，母親の妊娠中の外部からの影響を調べることであり，「催奇形性物質に よって, 先天異常の子どもは増えている」ことがまことしやかに語られた当時にあ って，カルテ収集は親たちがまずできる，行うべきことであった．親たちは個々に 担当医に依頼して妊娠中のカルテを出してもらう。それが難しい場合には，代わつ て木田盈四郎氏7がその医者に依頼して取り寄せる. 会員の妊娠中の投薬, レント ゲン照射，予防注射などの服用履歷が集められ，分析が行われた。そこから傾向と して見出されたのが，ホルモン剤服用率の高さであり ${ }^{8)}$, この事実は後に, 国・厚 生省に対する要求課題のひとつへと結びついていく.

この「父母の会」の国・厚生省への働きかけは, 幾度にわたってなされている. たとえば，その一例として，1978 年 10 月 6 日には，各政党と社会労働委員会全議 員に対して「先天性四肢障害児問題に関する質問並びに要望書」が提出され，回答 が求められた。その「質問並びに要望書」には，「1. 医薬品の安全性，副作用に対 する監視と黄体ホルモン剤使用の問題について対策をとること.2. 全ての催奇性 
物質の総点検をすること. 3. 先天異常センターの建設と疫学調査の実施を行うこ と. 4. 大学医学部に, 人類遺伝学研究体制の整備と人類遺伝学講座を設置するこ と. 5. 先天異常問題に関する諮問機関を設置すること.6.サリドマイド認定の問 題点と認定作業の継続を行うこと $\rfloor^{9)}$ といった, 当時の「父母の会」の主要な要求 課題が示されている。すなわち，大きく分けて，1. ホルモン剤を含めた催奇形性 物質のチェック体制の強化， 2 . 先天異常を専門に扱う機関の設立， 3. サリドマイ ド薬害の認定作業の継続, といった主要な 3 つの要求課題が提出された.

一方で, 地域に向けた啓発活動としては, 全国各地でシンポジウムや写真展の活 動が展開されている，たとえば，全国各地で開かれたシンポジウムでは，医者，環 境保護運動家, 教育者等のさまざまな演者が招かれ, さまざまな角度から先天異常 問題が扱われた。このシンポジウムを通じて,「先天異常の問題はけっして他人事 ではない」「いつ我が身の問題となるかわからない」. したがって,「行政や専門家 によって任せておけばよい問題ではなく, 一人一人の日常生活から, 各々の立場か ら, これについて考元, 行動を起こしていかなくてはならない」(先天性四肢障害 児父母の会 $1978 ： 2$ ) として, 子どもの障害がどの家庭にも起こりうる身近な問 題であることが訴えられた。

また，より地域に密着した啓発活動としては，デパートの一室や公民館，市民ギ ヤラリーなどを利用した写真展の活動が展開されている。とりわけ，二ホンザル奇 形問題研究会との共同で「奇形ザル展」が開かれ,「奇形ザル同様，子どもの障害 もまた，経済成長の犠牲によるものではないか」という疑問が提起された。「奇形 ザル展」を通じて,「餌付けされた野生のサルの群れに奇形が増えている」. それは 「人間の口にしている食べ物をサルが共有するようになったからだ」。したがって, 「サルの奇形は, 人間の奇形, 人類への滅亡の危機を象徵する」(先天性四肢障害児 父母の会 $1995 ： 175 ）$ と主張されたのである.

\section{3 科学(原因究明)のもつ効果}

では, 1970 年代における「父母の会」の原因究明の訴元は, この運動に携わっ てきた親にとっては，どのような意義をもっていたのだろうか. たとえば，米山政 弘氏は, 当時「父母の会」の原因究明活動に携わった動機を次のように語っている.

淡路島に奇形ザルを見に行ったんです．中橋［実］さんっていう方が［淡路 島モンキーセンターの] 所長でね, そこを訪ねに行ったんです。僕は変な話だ けどね，奇形ザルのなかでも遺伝していく，そういうことが見られるんじゃな いかなって思って接近したんです。でも当時はね, サルにも遺伝の障害が出て 欲しいっていう気持ちがあったんです。そうすると非常にわかりやすくなるか ら。環境と遺伝 [の関係］が．薬害による奇形と突然変異が出るということと． これは木田 [盈四郎］先生から教えてもらったことだけど，環境と遺伝はね密 接に切り離せない問題で，遺伝子というのは環境物質との相互作用で発現する 
というね。僕は遺伝というものの偏見をなくすというのは，いわゆるモラル的 な意味ではなくて, 普遍的にというか科学的にというかな, 障害児というのは ねこうして生まれるという, 誰でも生まれるというね。誰も遺伝子の成り立ち というものを全然わかっていないから，そういう非科学的な見方は許せないっ て。そういう見方 [木田先生の環境と遺伝が相互作用することで突然変異が生 じるという説明をを知ってから，それで世界がバーッとひっくり返るょうな ね ${ }^{10)}$.

米山氏は, 遺伝性と診断された障害の子どもをもつ親である.上の引用では, 「変な話だけども」と断りながら，氏が「サルにも遺伝の障害が出て欲しいという 気持ち」をもって, 淡路島の奇形ザルに接近したことが語られている.それは語り からもわかるように，(当時，環境污染の点から問題視されていた）淡路島の奇形 ザルのなかにも遺伝性の障害が見出せれば，「環境と遺伝は密接に切り離せない問 題」であり, 遺伝性の障害は「遺伝子自体のみならず, 環境物質との相互作用によ って発現する」こと, すなわち, 遺伝はその決定因ではないことが確認できるから である.こうして氏は, 子どもの障害について, その根本的な因果を家系や血筋と いった事柄の外部に見出そうとすることによって, 親への偏見や差別に対抗しよう とした。

一方で，こうした家系や血筋の外部に子どもの障害の因果を見出そうとすること で親への偏見や差別に対抗しょうとする向きについては，何も米山氏個人のみのも のではない.たとえば，「父母の会」を立ち上げた野辺明子氏もまた，設立当初は 「科学的に [子どもの障害の] 原因を究明することで, 偏見や差別を打破したいと いう気持ち」5)をもっていたことを語っている．障害の原因を科学的に究明するこ とで，子どもの障害が潜在的には誰にでも起こりうること，家系や血筋によるもの ではなく，また親の決定や判断によるものでもないことが確認できる. 米山氏が, 遺伝の場合でも環境要因の影響があることを知って「世界がバーッとひっくり返 る」体験をしたと語っているように，原因究明の訴えはそれそのものが，子どもの 障害が「家系や血筋によるものではない」こと，「親のせいではない」ことが確認 されることによって, 親にある種の解放の効果をもたらすのである ${ }^{11}$.

\section{0 年代一一当事者(親・子ども)／日常生活への立脚}

\section{1 原因究明の行き詰まり}

これまで見てきたように，1970 年代における「父母の会」の運動は，子どもの 障害を環境污染の点から捉え, 催奇形性物質の特定・除去を求める運動として展開 された．だがその後，80 年代に入ると，この原因究明の訴えは次第に停滞へと追 い込まれていく.

まず，会内部での問題として，「父母の会」がこれまで独自に取り組んできた原 
因究明の試みは, 1970 年代の終わり頃には, 次第に「いくつかの疑わしい物質が 浮かびあがるものの, 原因を特定するのが難しい」(先天性四肢障害児父母の会 1989 a: 75）という事態に直面していく．たとえば，ホルモン剤を例にとれば，ホ ルモン剤を投与する切迫流産の可能性のある母親という時点において，すでに四肢 奇形の発生率の高い層が選抜されていること。また, 仮にホルモン剤に催奇形性が 認められるとしても, サリドマイドのように強力なものではないために, 明確に因 果関係を立証することは困難であることが実感されるようになる。

こうしたことから,「父母の会」の活動は, 原因の特定困難という事態に直面す るなかで,一方では, 学校の音楽の授業で使用する改良笛の問題等, 子どもが日常 に直面する問題へと傾斜していく（ただし，療育問題への取り組みは設立当初から あり，また改良笛問題への取り組みも，1978 年には取り組まれている)。たとえば， 改良笛問題への取り組みでは，各自治体や各教育委員会に改良笛の開発，公費負担， 他の楽器の使用等を要求する (先天性四肢障害児父母の会 $1993: 11$ ). 他方では, 原因が特定できないにせよ，まだ疑わしい物質があることから，究明活動を続けて いこうとする動きがある. 黄体ホルモン剤ドーギノン, つわり止めベンデクチン, 枯葉剤等のさまざまな物質の究明活動が続けられる. だがその活動も, 具体的な成 果を上げることができずに, 80 年代後半までには停滞していく.

次に, 会外部からの影響として, この時期, 胎児診断や選択的中絶といった二次 予防対策推進の動きが顕著になることから，親たちは次第に原因究明の訴えのもつ 危険性に敏感にならざるをえなくなっていく.

まず，1979 年には，厚生省内部に「本格的に先天異常のモニタリング・システ ムの構築に取り組む」という名目で，先天異常のモニタリングに関する研究班（以 下，「モニタリング研究班」）が発足する.「父母の会」は当初，「モニタリング研究 班」の発足を知り，素朴にこれまでの「父母の会」の訴えを反映させるものとして 期待していた。 だがその後,「モニタリング研究班」との交渉や報告書等から,「モ ニタリング研究班」の調查研究が遺伝子診断や胎児診断に力点を置いたものである ことが判明し，親たちは次第に「モニタリング研究班」への警戒を強めていく．と りわけ，85 年 9 月には，母子保健法改正案が国会に上程される動きを知り，この 法案の指針のひとつが先天異常児の出生を監視する新生児モニタリングシステム （一次予防）を名目に，遺伝相談や胎児診断（二次予防）を推進するものであった ことから，親たちはこの動きに対して真っ向から異議を申し立てる意見書を提出す る（先天性四肢障害児父母の会 1989 a: 117-24）.

次に, この二次予防対策推進の動きにも関わって, 反公害・反薬害運動と対立し ていた障害者解放運動の批判の矛先が,「父母の会」の原因究明の訴えにも向けら れるようになった点である．たとえば，1984 年 11 月には，「全国青い芝の会」と のあいだで話し合いの席が設けられている ${ }^{12)}$.「父母の会」の原因究明の訴えは, 「障害児の出生を『あってはならない, 特別なこと, 不幸なこと』とする考えから 出発しているのではないか. だとすると, その出発点から障害者差別の契機を含ん 
でいるのではないか」.こうした点が，「父母の会」への批判の焦点となった.

もちろん，こうした「全国青い芝の会」からの批判に対しては，「いや，障害児 の障害は単なる自然な障害ではなく, 人為的な障害，あるいは『傷害』である。と すれば，その原因と加害者を徹底的に追及しなければならないのではないか」（先 天性四肢障害児父母の会 1989 a: 112-4）として応じることは可能である。すなわ ち，一次予防と二次予防との区分を再確認することである。たとえば，先述した 「父母の会」の母子保健法改正反対の意見書では，「モニタリングとは本来，有害物 質を監視し，除去するためのものであり，障害児の医療や福祉とは別問題である」 （先天性四肢障害児父母の会 1989 a：125）として，加害者を紏弾すること自体は重 要であることが確認されている。また，「全国青い芝の会」との話し合いの席でも， 「その子が障害児として生まれ，そして生きていくという問題は別であり，[これま で「父母の会」は］障害児の発生予防ではない，障害の原因究明を行ってきた」 ${ }^{12)}$ という反論がなされている.

だが総じて見れば，その後「父母の会」の親たちは，こうした対応とは別に，無 批判に原因究明の訴えを展開することはできなくなっていく．親たちは少なからず， 原因究明の訴えが別様に把握されて受け取られることの危険性を認識していくので ある。

\section{2 親と子どもの当事者性の相違}

こうして 1980 年代に入ると, それまで自らを被害者家族として位置づけ展開し てきた原因究明の訴えは，次第に行き詰まりを見せるようになる。結論を先取りす れば，その後「父母の会」の運動は，親と子どもの当事者性の相違を認識した運動 へ，具体的には「子どもの障害はあってもよい」という運動へと，その主張の有り 様を転換していく.

\subsection{1 親の側の当事者性}

ここではまず，「父母の会」の「子どもの障害はあってもよい」という主張への 転換について, 親の当事者性という点から, その前提・契機となっている点を確認 しておきたい. 紙幅の都合上, 以下の 2 点のみを指摘する.

まず，親たちが「子どもの障害はあってもよい」と思えるようになる，主張の転 換の前提として,「父母の会」の親に帰属する, 子どもの障害にかかる諸々の負担 の実質的な少なさがあるというべきである。a )「父母の会」の場合には，もとも と障害が軽く，親の負担が少ないことに加えて，b）その頃には，子どもの成長や 成人会員の助言から，親の将来的な不安が軽減されていたことまま，c） 1970 年 代の活動を通じて，その活動の効果として，親たちが障害への偏見や差別から一定 程度解放されていたこと.d）そして松原洋子によれば，その頃から「優生」への タブー認識が浸透し（松原 2000：223-4），別の把握をすれば，社会的に障害への 偏見や差別が正当化されなくなることである.すなわち，ここで挙げられているの は，親にとって障害が障害（害・不都合なもの）でなくなること，つまり，障害が 
恣意的に否定的価值を付与された属性に過ぎなくなる（近づいていく）それも d ） より，社会に向けて障害への偏見や差別を告発しやすくなるという事態を指してい る.

次に，一次予防と二次予防との区分による対応ではない，積極的に「子どもの障 害はあってもよい」という点から二次予防を否定する契機として, 二次予防対策推 進の動きや優生の社会問題化による, 親の障害への偏見や差別の再認識がある. た とえば，障害をもつ子どもを生むか生まないかが親の決定の対象とされることによ って，もしくは周囲にそれが可能であると見なされることによって，あらためて親 は障害児を生んだ責任を問われるようになる。

私が期待していた科学というものが，胎児診断などをすることによって，逆 に生まれてよい命と淘汰した方がよい命，命が淘汰されていく時代になったん だっていうのが，私うう் 80 年代なんです。障害児を生んだ嫁としても， 肩身の狭さ，自分を責める自責の念が，新しい技術が普及することよってさら に追い討ちをかけるように，障害児を生んではいけないんだっていう，生まな くてもすむ時代なのになんで生まれてきたの?っていう見方が普通の人の心の なかにもう芽生えている. 科学によってもう一度レッテルを貼られていく，そ ういう感じを受けたんです5). [傍点部，筆者強調]

1970 年代の原因究明の訴えが，科学的に子どもの障害が「家系や血筋によるも のではない」こと,「親のせいではない」ことを確認させることによって, 親に解 放の効果をもたらすものあったとすれば， 80 年代以降の「新しい [科学］技術の 普及」は，逆にその責任を親に問いただすようになる，とりわけ，この二次予防対 策推進の動きに敏感であったのが, 遺伝性の障害の子どもをもつ親たちであった。 遺伝性の障害の子どもをもつ親たちにとって，ここで挙げられている胎児診断等の 技術の普及は，第二子および孫の出産の問題等にも関わり，けっして無関心ではい られない事柄だからである。

また実際に，本格的に会全体として遺伝性の障害の子どもをもつ親の問題が議論 されるようになったのは, 1980 年 10 月の渡部発言 ${ }^{13)}, 82$ 年の優生保護法改正の動 きをきっかけとしてである ${ }^{14)}$. たとえば，渡部発言では，遺伝性の障害をもつ者は 自発的に断種することが望ましいとされたが，遺伝性の障害の子どもをもつ親たち は，この発言を聞き捨てならないものとして批判を展開した。また，親たちはこの 時期, 優生保護法についても第 1 条「不良の子孫」のなかに「父母の会」の疾患が 含まれていることを知り,さらにはそれ以前にも胎児条項導入等の動きがあったこ とを知ることから，あらためて障害への偏見や差別を再認識していく（先天性四肢 障害児父母の会 $1995 ： 259-67)$.

\subsection{2 子どもの側の当事者性}

では, 子どもの当事者性についてはどうであろうか. 親たちはいかにして, 親と 
子どもの当事者性の相違に気づいていくのだろうか.

まず，親たちは 1980 年代以降，それまで展開してきたシンポジウムや写真展の 活動を継続させながら，この活動の内部でそれまでの主張の有り様を見直していく. 親たちはただそれまでの原因究明の訴えが停滞に追い込まれていくからというだけ ではなく，子どもたちとより積極的に向き合うようになるなかで，新しい主張の有 り様を模索していくのである。とりわけ，全国各地で展開されていた写真展の活動 のなかには, 一部の支部で早くも 80 年代前半に, 親の葛藤や主張の転換の萌芽を 見出すことができる.

父母の会では環境污染のシンボル的な存在としてマスコミに度々取り上げら れていた手足の欠損したニホンザル（奇形ザル）の写真展を全国各地で開いて いた（1970 年代後半）が，「サルといっしょに私の写真を飾らないで」と小学 生の女の子は訴えた. 原因究明活動そのものというより, 四肢障害の子どもを ありのままの姿で受けとめられない親の気持ちに潜む矛盾に対しての子どもか らの異議申し立てであったかもしれない。（野辺 2000：114）

1970 年代における「父母の会」の写真展では, 子どもの障害が環境污染によっ て生じたことを主張するために，奇形ザルと子どもの写真を一緒に並べてきた（3. 2 で見た「奇形ザル展」).だが親たちは，こうした問題提起の仕方に次第に疑問を もつようになる。たとえば，ある親は，機関紙のなかで「確かにたくさんの人が見 にきた。高校生もクラス単位でゾロゾロと訪れた。しかし無責任に見るだけで勝手 な好奇心を満足させて帰ってしまう」（先天性四肢障害児父母の会 1995：177）と 述べて，写真展を開いた達成感とは別にわだかまりの感情をもったことを訴えてい る。また上の引用でも，「四肢障害の子どもをありのままの姿で受けとめられない 親の気持ちに潜む矛盾」が問題にされているように, 他の親のなかからも「奇形と いう言葉が社会で差別的に使われている状況を認めながら，先天性四肢障害と奇形 という言葉は両立しないのではないか」（先天性四肢障害児父母の会 1995：177-8） といった疑問の声が上がるようになる。

だが実際には，上に見るような親たちの反省を促した契機（親たちが「奇形ザル 展」に違和感をもつようになった契機）としては，この時期（1980 年代前半）よ り少し前，会内部で成人会員 ${ }^{15)}$ の意見が繰り返し語られるようになったことがある。 確かにそれまでにも，子どもの側の意見が機関紙に取り上げられることはあったが， その多くは児童の意見であり，親の側の意向を先取りしたものであったことから， 正面切って障害者の側からの意見が語られることはなかった。これに対して，1979 年には成人会員がシンポジウムに登壇し，これをきっかけにして，障害者の側の意 見が会内部で繰り返し語られるようになる。たとえば，成人会員の本多眞由理氏は， シンポジウムの席で「父母の会」の原因究明の訴えへの違和感を次のように語って いる。 
障害者が増えている原因を追及し，なくすべきなのだ，それはどうも○○と いう薬がいけない, といっても問題提起になりますね. ですがもうすでに, 当 の本人は障害者にとって理想的とはいえない社会の中で，五体不満足のままで 十分，精一杯生きているのです。……れからだって——平気で生きていける といえば強がりになるのでいえませんが——生きていけるだろう。五体揃って いるのが理想的なのでしょうが，揃っていないからといって欠陥人間ではない

し，不自由だとは思わない．（先天性四肢障害児父母の会 1982 b: 91-2）

本多氏が最後に語る「不自由だとは思わない」という点は，「父母の会」の障害 が先天性であることが関わっているが，少なくともここでは障害者の側から，「父 母の会」の原因究明活動への違和感が語られていることが確認できる。また同様に, このシンポジウムの席で成人会員の志沢小夜子氏も,「ずいぶん生活も不自由でし ょうなんて人が言ったりしても，そういう感じがほとんどない」(先天性四肢障害 児父母の会 $1982 \mathrm{a}: 227-8)$ と述べて，すでに障害をもって暮らす自己のありのま まの姿を語っている.

その後,「父母の会」にいる成人会員たちは,「会活動にさまざまな形で参加し, 父母の会活動を支えて」（先天性四肢障害児父母の会 1995：281）いく.たとえば， 『さっちゃんのまほうのて』（成人会員の志沢氏および田畑精一氏・「父母の会」・野 辺氏の共同制作）をはじめとして，「父母の会」の出版物には，多くの場合に成人 会員が本の編集に携わっており, ここからも成人会員の運動への強い影響力を確認 することができる.

\section{3 日常生活に立脚した活動の展開}

その後,「父母の会」の写真展は, 1980 年代前半には「生まれながらにして四肢 に障害のある子どもたちの写真展（子どもだけの写真を並べた写真展）」へ，そし て 80 年代後半には「いのちはずむ仲間たちの写真展（子どもの笑顔や躍動感あふ れる姿を強調した写真展)」へと, そのタイトルも内容も変わっていく. 子どもた ちの写真を見て「かわいそうだ」と感じさせてしまう「環境污染，社会の犠牲者と しての子どもの症例の写真」が並べられた写真展に代わって, 訪れる者が「友人の 写真を見ているようだ」(先天性四肢障害児父母の会 $1995 ： 179$ ) と感想を残すよ うな，子どもの日常生活に焦点を当てた，子どもの生き生きとした姿の写真が並心゙ られた写真展が展開されるようになる.

また，それまで継続して展開されてきたシンポジウムも，子どもの障害の原因究 明を訴えるのではない, 子どもが主役の「子どもシンポジウム」が開かれるように なる.「子どもシンポジウム」では, 子どもたちが直接壇上に立って作文を朗読し たり, 改良楽器の演奏を披露する，たとえば，1983 年に埼玉支部で開かれた「子 ぞもシンポジウム」では，「いのちを語りはじめる子どもたち」と銘打たれ， 250 人以上の参加者が注目するなかで,「子どもたち自身が自分の体験や考えているこ 
とを」(先天性四肢障害児父母の会 1995 ：188）語った。「子どもシンポジウム」は， 親たちにとって, 普段家庭では聞くことのない子どもの素直な声に耳を傾ける機会 となった（先天性四肢障害児父母の会 $1995 ： 189$ )。

一方で，1980 年代後半以降には，『ぼくの手，おちゃわん夕イプや』(1984 年) や『いのちはずむ仲間たち』（1989 年）など，数々の「父母の会」の出版物が発行 されていく，それらの出版物は，「親や子どもの手記や作文，あるいは子どもたち が成長の折々に，ふとつぶやいた言葉の断片を収録して，彼らの日常の姿をあるが

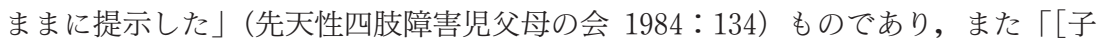
ぞもたちが］家族と一緒に地域社会の中で生きている，ごく当たり前の生活」（先 天性四肢障害児父母の会 1989 b: 106）を描き出したものである。そこには，それ まで支部が地道に発行してきた文集からの手記をはじめとして, 多くの子どもたち をボランティアとして巻き込み，「子どもが育つ場所」(先天性四肢障害児父母の会 1995：146）として開かれてきたスキーキャンプの活動等の記録が収められている.

また, これらの親子の日常生活に立脚した活動と並行して展開されてきたのが, 遺伝や優生に関する問題の提起であり，具体的には「障害児は生んではならない」 「障害児のいる家庭は不幸である」という見方に対する異議申立てである。たとえ ば，ある遺伝性の障害の子どもをもつ親は，「望んで障害児を生む私はおかしいの でしょうか.……[私たちの家庭は, ] ごく普通の楽しい家庭です。こんな楽しい 家庭を間違っているとか正しいとか, 誰が決められるのでしょう」(先天性四肢障 害児父母の会 $1995 ： 265-6)$ と述べて，障害児を生ませないようにする二次予防対 策推進の動きに疑問を呈している。また, 1980 年代以降には, 先述の「子どもシ ンポジウム」のみならず，遺伝や優生の問題を扱うさまざまなシンポジウムが開か れるようになる，「育てる，ということは実は彼らのかわいらしさ，彼らと生きる ことの面白さを一つ一つ手にしていくことでもあって，その状態は決して『不幸』 ではない」(先天性四肢障害児父母の会 1989 a: 90). 親たちは，自身の日常生活に おける実感を根拠にして,「障害をもった子どものいる暮らしはけっして不幸では ない」ということを示していく.

\section{5 結}

本稿では,「父母の会」の運動の展開を追い，そのなかで親たちが，いかにして その主張の有り様を転換させてきたのかを明らかにしてきた。

1970 年代における原因究明の訴えは，80 年代以降に展開された運動から見れば, 親と子どもの視点を同一視したうえで展開された運動であった。たとえば，70 年 代には「子どものために原因を究明しなくてはならない」「先天性四肢障害を『被 害』ととらえ，……の原因を明らかにすることは親の当然の責任である」(先天 性四肢障害児父母の会 1989 a: 70）といったように，親たちは自らを被害者家族と して位置づける一方で，家族内部における親と子どもの当事者性の相違については 
十分に認識することはなかった。

また，「父母の会」の運動が，1980 年代以降に親と子どもの当事者性の相違を認 識した運動として展開されるようになった点は, 親たちのもつ障害に対する捉え方 の変容からも確認できる。つまり，それまで親たちは，「子どもにとつても障害は ない方がよいもの，あってはならないもの」であることを前提として原因究明を訴 えてきたのに対して, 80 年代以降には, 子どもの視点に立つことから障害をもつ て生きる子どものありのままの姿を受けとめていく，親たちは，社会に向けて，障 害をもって暮らす子どものありのままの日常を示すことによって，「障害をもった 子どものいる暮らしはけっして不幸ではない」ということを訴えていく.

\section{[注]}

1）現在，「父母の会」は，70 万部を超すロングセラーとなった絵本『さっちゃんのまほうのて』 で多く知られている. 先天性四肢欠損症の子どもをもつ親を中心に，1400 家族ほどが参加する. ここでの聞き取り調査にあたっては, 2004 年 8 月から 11 月までのあいだに, 野辺氏をはじめ 1970 年代当時に積極的に活動されていた方々（奈良支部の西村圭也氏，長野支部の米山政弘氏， 茨城支部の佐藤和江氏）に依頼した。また，資料を得るにあたって事務所の方々にお世話にな った. 御礼申し上げる.

2）高度経済成長期における施設拡充の動き，「全国重症心身障害児(者)を守る会」の運動につい ては，すでに別の稿で論じている（堀 2006）。重症児の親の運動は，「全国重症心身障害児 (者)を守る会」の理念として揭げられている「守る会の三原則」や「親の憲章」に見るよう に, つねに会員に「親としての心構え」を促すなかで展開されてきた。この運動は, 1967 年の 児童福祉法改正等, 施策の内実に直接的な影響を及ぼしていく.

3）それまでの親の側による減刑嘆願運動については，たとえば，「全国重症心身障害児(者)を守 る会」の機関紙『両親の集い』「特集——と絶たぬこの悲劇」(1967 年 9 月号) 等を参照.

4）この時期の「青い芝の会神奈川県連合会」の機関紙『あゆみ』のバックナンバーは, 神奈川県 社会福祉協議会社会福祉情報センターに所蔵されている。また,「青い芝の会神奈川県連合会」 と「神奈川県心身障害者父母の会連盟」との話し合いの記録は, 『福祉夕イムズ』第 221 号に その全容が掲載され，『あゆみ』に収められた記録はこの再掲である.

5） 2004 年 9 月 17 日. 野辺明子氏からの聞き取りデータ.

6） 2004 年 11 月 5 日. 西村圭也氏からの聞き取りデータ.

7）木田氏は「父母の会」の顧問であり, 臨床奇形学の専門医である. サリドマイド認定委員のひ とりとしてサリドマイド裁判に関わり，その後もサリドマイド福祉センター「財団法人いしず え」の医療顧問として活動を続ける.

8）たとえば，1978 年 3 月に集計が行われた「父母の会」の調査では，母親 181 名中 53 名がホル モン剤を服用していたことが判明した。この事実は後に,「なぜ先天異常児に？母の 3 割ホ ルモン剤服用——親の会実態調査」(『産経新聞』1976.5.5 朝刊) 等, 新聞各紙にも取り上げら れる。

9） 2004 年 11 月 1 日. 佐藤和江氏よりいただいた，氏自身が整理・作成したデータから.なお, 
この要望書は, 後述する 1979 年の「モニタリング研究班」発足前の要望書であり, したがっ て, それ以降「父母の会」の主張が変わる前の 70 年代における国・厚生省への要求課題をほ ぼ網羅している.

10） 2004 年 11 月 19 日. 米山政弘氏からの聞き取りデータ.

11）確かに，本節を含め「父母の会」の運動の展開全体から，「父母の会」の運動は，「新しい社会 運動論」で議論されるような新しい社会運動としての典型的な諸特徵をもつとして, 指摘可能 かもしれない. だが，A.トゥレーヌ $(1978=1983)$ や J ハーバマス $(1973=1979)$ に代表さ れる新しい社会運動論の本来的関心は，新しい社会運動を（後期資本主義といった）歴史的構 造的文脈に位置づけ，その生成の意味を理解することにあり，その関心はあくまでも巨視的な 時代把握にあるといえる.

12） 2006 年 1 月 14 日.「全国青い芝の会」との話し合いについては，そのときの議事録をもとに野 辺氏から口頭で同ったもの.

13）渡部発言とは，上智大学教授渡部昇一の『週刊文春』（1980 年 10 月 2 日号）「古語俗解」欄に 掲載された「神聖な義務」と題されたエッセイのことである。このエッセイでは, 血友病患者 である大西赤人の高額な医療費が言及され，遺伝性の疾患をもつ者は生まないのが「神聖な義 務」であると主張された.

14）「父母の会」の設立趣意書には，「“先天異常，即ち遺伝である”との古い因習や偏見が，特に 地方などにはまだ根強く残っており，そのことのために，子供やその家族が受ける精神的苦痛 も少なくありません」（先天性四肢障害児父母の会 1995：341）と明記されているように，そ れまで「父母の会」の運動は, 遺伝への偏見や差別を不問もしくは追認したままで展開されて きた。

15）「父母の会」には，設立当初から，少数ながら親ではなく障害者本人として会活動に参加する 者が存在し，現在でも彼／彼女らを成人会員と呼んで正会員として扱っている.

\section{[文献］}

青い芝の会神奈川県連合会，1970，「小特集一一話し合いをめぐって」『あゆみ』11：2-7.

Habermas, Jurgen, 1973, Legitimationsprobleme im Spatkapitalismus, Frankfurt am Main:

Suhakamp. (=1979, 細谷貞雄訳『晚期資本主義における正統化の諸問題』岩波書店.) 堀智久，2006，「重症児の親の陳情運動とその背景」『社会福祉学』日本社会福祉学会 47 (2)：31-44. 石川准，1995，「障害児の親と新しい親性の誕生」井上眞理子・大村英昭編『ファミリズムの再発

見』世界思想社：25-59.

梶田孝道，1991，「戦後日本の社会運動——『開発国家』と『日本的特質』に着目して」社会運動

論研究会編『社会運動論の統合をめざして——理論と分析』成文堂：179-201.

春日キスヨ，2001，『介護問題の社会学』岩波書店：77-114.

松原洋子, 2000,「日本——戦後の優生保護法という名の断種法」米本昌平・松原洋子・勝島次

郎・市野川容孝『優生学と人間社会』講談社：170-236.

似田貝香門，1976，「開発政策＝計画と住民運動——住民運動の提起している諸問題」松原治郎・

似田貝香門編『住民運動の論理』学陽書房：201-45.

58 (1) 72 
野辺明子, 2000,「障害をもついのちのムーブメント」栗原彬・小森陽一・佐藤学・吉見俊哉編

『語り—つむぎだす 越境する知 2 —東京大学出版会 : 105-29.

岡原正幸, 1990,「制度としての愛情——脱家族とは」安積純子・尾中文哉・岡原正幸・立岩真也

『生の技法——家と施設を出て暮らす障害者の社会学』藤原書店：75-100.

先天性四肢障害览父母の会，1975，『会報』1．

，1978，『先天異常問題 会報』3 .

編，1982 a，『シンポジウム先天異常 I ——人類への警告』批評社.

編，1982 b，『シンポジウム先天異常 II——いのちを問う』批評社.

編著，1984，『ぼくの手，おちゃわんタイプや——先天異常と子どもたち』三省堂.

， $1989 \mathrm{a}$ ，『いのちの今日・明日一一先天異常の原因究明をめぐって 会報』5.

，1989 b，『いのちはずむ仲間たち』少年社.

—，1993，『父母の会とリコーダー——手に障害を持つ子にとってリコーダーとは何か 会 報』6.

，1995，『父母の会の 20 年 会報』7.

Touraine, Alain, 1978, La voix et la regard, Paris: Seuil.（=1983，梶田孝道訳『声とまなざし

——社会運動の社会学』新泉社.)

土屋葉，2002，『障害者家族を生きる』勁草書房.

横塚晃一，[1975］1981，『母よ！殺すな』すずさわ書店.

要田洋江，1986，「『とまどい』と『抗議』——障害児受容過程にみる親たち」『解放社会学研究』

日本解放社会学会, $1: 8-24$.

—，1994，「現代家族と障害者の自立一一日本型『近代家族』をこえて」『家族社会学研究』

日本家族社会学会：65-79.

全国重症心身障害児(者)を守る会，1965，『両親の集い』1.

（原稿受付 2005.9.18 掲載決定 2007.1.22） 


\title{
From Emphasis on the Determination of the Causes of Birth Defects to Emphasis on the Daily Life of Parents and Children \\ : Association of parents of children with congenital limb defects in the $1970 \mathrm{~s}$ and $1980 \mathrm{~s}$
}

\author{
HORI, Tomohisa \\ University of Tsukuba \\ thori@social. tsukuba.ac.jp
}

This paper aims to reexamine the activities of the Association of Parents of Children with Congenital Limb Defects in order to explore the manner in which the assertions of parents have changed.

The Association of Parents of Children with Congenital Limb Defects was established in 1975. This was a time when attention was being focused on the various problems involving environmental pollutants; it also marked the beginning of movements towards determining the cause of disabilities in children. Parents perceived themselves as victims, and while urging the Ministry of Health and Welfare and other government agencies to identify and eliminate teratogenic substances, they also held symposiums, photo exhibits and other activities to educate society and prevent their recurrence. These movements that aimed at determining the cause of the disabilities in children had the effect of releasing parents from their burden by confirming that the disabilities in their children were not the result of familial or genetic factors, and hence, they were not responsible for these defects.

Beginning in the 1980s, however, appeals to determine the cause of birth defects by the association began to diminish. In particular, the manifestation of the sense of incongruity with activities to determine the cause of birth defects and the assertion that having a disability does not necessarily prevent a disabled person from leading a prosperous and fulfilling life resulted in a fundamental transformation in the nature of these movements. Subsequently, parents noticed differences in the relationships that they shared with their children, and the association began to carry out movements that emphasized the daily life of 
parents and children. Events such as symposiums and vibrant photo exhibits of children with disabilities suggest that "they are as happy as ordinary families." This paper attempts to clarify the differences in the nature of these movements during the 1970s and 1980s by examining their execution.

Key words: disability, family, social movements

(Received September 18, 2005 / Accepted January 22, 2007) 